\title{
Copyright law and the promotion of scientific networks: some reflections on the rules on co-authorship in the EU
}

\author{
Giulia Priora \\ SJD Candidate, Central European University
}

In the digital era the co-creation of content by several authors has become easier in a number of ways. Networks, the symbol of today's information society, are reshaping and supporting our communication, education, creativity and professional development. Embracing the prospective of co-creators, this paper aims to provide a new insight into the on-going debate on the effectiveness of copyright rules in the European Union (EU). The focus lies on the scientific sector, which offers both empirical evidence of the co-production phenomenon and specific policy goals set by the EU legislator with regard to collaborative knowledge production. The analysis shows how the EU copyright framework neither includes a comprehensive body of harmonized rules on co-authorship nor displays prospective plans to do so, while the related national regulations present highly diverging approaches. The paper highlights how the impact of this regulatory inhomogeneity is increasingly at odds with the policy objective of a collaborative and high-profile European Research Area, thus calling for a more substantial harmonization under an inclusive definition of co-author and an enhanced valorization of joint endeavours in the networked system of production of knowledge.

Keywords: co-authorship, EU copyright law, network society, scientific sector

\section{INTRODUCTION}

In the post-industrial era technological advancement, human effort and effective regulations remain key ingredients for economic development. At the same time, since the 1970s all these factors have been undergoing a remarkable digital transformation, with interconnected information devices (computers and phones in primis) entering the stage and impacting upon the modes of production. ${ }^{1}$ The digital era has been epitomized by numerous notions, among which the network society is a concept that encompasses particularly well the most salient aspects of the transformations caused by digital technologies. As explained by sociologist Manuel Castells, the term manages to convey that both structures and outcomes of our social and economic relations have acquired a new defining shape. ${ }^{2}$ Indeed, networks - or what Castells would rather call 'the networking logic' at the basis of the informational society ${ }^{3}$ - are today a constant presence in everyday life, starting from systems of communication, education and professional development. As historians have highlighted, the digital transformations of the late twentieth and twenty-first centuries are characterized by such a remarkable

1. Manuel Castells, The Rise of the Network Society (Blackwell, Oxford 2010) 51-4.

2. Ibid 70-72.

3. Ibid 21. 
degree of pervasiveness as to enable comparisons to be drawn with the Industrial Revolution or even the invention of letterpress printing. ${ }^{4}$ As for these two cornerstones of human progress, the main factor of impact on the social and economic orders lies in the enhancement of productivity, and digital networks achieve this by way of facilitating interactions and collaboration. ${ }^{5}$ This is utterly true also in the field of the creation of artistic, literary, musical, audio-visual and scientific works. Since the early developments of the creative industries, joint creation has been a known scenario in the production of movies, songs, newspapers, encyclopaedias and other works which similarly require the expertise and efforts of multiple contributors. ${ }^{6}$ The recent weaving of digital networks is shown to favour collaborations in and across the creative sectors, from the rise of notions such as co-design, to the internationalization of work teams, to the interoperability of created content on several physical supports, up to the co-writing of scientific articles. ${ }^{7}$

The consolidation of collaborative trends begs the question of whether the rules on the co-creation of content are evolving alongside the digital networks. Great attention has been paid by policymakers and law experts to rethinking provisions concerning the legal relations of private individuals in the network society, yet a general level of cautiousness has been maintained towards comprehensive projects of regulatory reforms. The European Union's (EU) legislator fully embodies this twofold attitude, as it turns the initial enthusiasm for the economic benefits of the digital technologies into a more sectorial and cautious analysis of online market behaviours. ${ }^{8}$ From the particular perspective of copyright law - the legal discipline playing the most pivotal role in the creative industry - the digital transformations occurring within the network society carry two striking implications: on the one side, a massive increase in the demand for content and, on the other, exacerbated difficulties in the enforcement of copyright holders' exclusive rights in the online environment. ${ }^{9}$ These two most immediate (yet, not sole) effects represent the vast majority of the legal issues raised and decided upon

4. Melvin Kranzberg and Carroll W Pursell (eds), Technology in Western Civilization (OUP, New York 1967).

5. ' $\ldots$ under the new historical conditions, productivity is generated through and competition is played out in a global network of interaction between business networks' Castells (n 1) 77.

6. Marjut Salokannel, 'Film Authorship in the Changing Audio-Visual Environment' in Brad Sherman and Alain Strowel (eds), Of Authors and Origins: Essays on Copyright Law (Clarendon Press, Oxford 1994) 57-9.

7. Caroline S Wagner and Loet Leydesdorff, 'Network Structure, Self-Organization and the Growth of International Collaboration in Science' (2005) 34 Research Policy 1608-18.

8. The so-called Digital Agenda for Europe, launched in 2010, first introduced the internet as leading input into structural changes in the economy. Under the ideas of 'smart work' and 'digital way of life', the EU Commission envisioned inclusive economic growth and higher living standards for its citizens by boosting investments and overcoming the fragmentation of markets. See European Commission, 'A Digital Agenda for Europe' (Communication) COM(2010) 245 final/2, 26 August 2010. After six years, while new online business models were exponentially growing, the attention on the promotion of investments moved to the rights and obligations of the digital market actors. In this vein, the European Commission complemented its digital agenda with specific guidance related to the collaborative economy and an on-going reform of copyright rules. See, respectively, European Commission, 'A European Agenda for the Collaborative Economy' (Communication) COM(2016) 356 final, 2 June 2016 and European Commission, 'Towards a Modern, More European Copyright Framework' (Communication) $\operatorname{COM}(2015) 626$ final, 9 December 2015.

9. For specific analysis on these two aspects, see Irini Stamatoudi (ed), Copyright Enforcement and the Internet (Wolters Kluwer, Alphen aan den Rijn 2010); Mark-Oliver 
in courts. This leads not only tribunals but also scholars to comment primarily on problems related to the demand and supply of created works, that is to say on the circulation of the objects of copyright protection, ${ }^{10}$ overshadowing its subjects. As Jane Ginsburg suggests, greater attention ought to be paid to the authors, the 'constitutional subjects of copyright', ${ }^{11}$ focusing on by whom, why and how content is created in the network society, as the array of options concerning the creation, publication, commercialization and exploitation of the works is in progressive expansion, and their decisions ultimately dictate the functioning of the markets. In this vein, the phenomenon of co-creation stands out as a significant factor of impact in the creative process. Yet, as highlighted by Alexander Peukert, in the application and interpretation of copyright rules 'most statements deal with exclusivity as a kind of monolithic block. No distinction is made depending on whether one or several owners are involved'.$^{12}$

This paper aims to explore the legal institute of co-authorship in light of the expanding phenomenon of co-production, presenting two main constraints of scope. The first limitation is one of jurisdictions, as the article takes into consideration the European region, with a focus on the EU legal framework and a deeper study of selected national regulations. Secondly, the paper deals with the scientific sector - one, and surely not the most representative, branch of the creative industries as a whole. The choice of this specific field is justified by the wide availability of reliable and compiled data on collaborative trends and the presence of unambiguous policy goals at EU level in regard to the scientific sector. The article looks at the international and EU legal frameworks, in search of uniform provisions regulating co-authorship. The analysis then moves to the national level, where regulatory divergences will be highlighted by illustrating the profoundly different approaches of the German and French legislators. Supporting data about the expansion of the co-production of scientific knowledge will be provided, building an up-to-date assessment of the legislation on co-authorship and inquiring whether more substantial EU harmonization is needed to better pursue the policy goal of an effective and collaborative European Research Area.

\section{THE LACK OF SUBSTANTIAL HARMONIZATION OF RULES ON CO-AUTHORSHIP}

Copyright law fundamentally stands on the figure of the author, the individual person creating original content and enjoying exclusive rights over it. ${ }^{13}$ But what if a work is created by more than one person, be it the case of two individuals combining their efforts and skills or, rather, of a larger collective of contributors? As Arthur Waldenberger highlighted three decades ago, the phenomenon of co-creation is anything

Mackenrodt, 'Assessing the Effects of Intellectual Propery Rights in Network Standards' in Josef Drexl (ed), Research Handbook on Intellectual Property and Competition Law (Edward Elgar, Cheltenham 2008).

10. Jane C Ginsburg, 'The Concept of Authorship in Comparative Copyright Law' (2002) 52 DePaul Law Review 1067.

11. Ibid 1063.

12. Alexander Peukert, 'Individual, Multiple and Collective Ownership of Intellectual Property Rights - Which Impact on Exclusivity?' in Annette Kur and Vytautas Mizaras (eds), The Structure of Intellectual Property Law: Can One Size Fit All? (Edward Elgar, Cheltenham 2011) 196.

13. Ginsburg (n 10) 1063. 
but new in the history of arts, literature, music and cinematography. ${ }^{14}$ Since its origins in early-eighteenth-century Europe, the traditional copyright paradigm has foreseen the possibility of co-authorship. ${ }^{15}$ Interestingly, national copyright regulations have developed highly varying terminology, definitions and approaches to the legal institute of co-authorship. The remarkable diversity at national level did not pass unnoticed by the drafters of the Berne Convention of 1886 - the first main international agreement on copyright law, with over 170 signatory countries. ${ }^{16}$ Agreement was reached only on one rule concerning co-authorship, which provides for the duration of the copyright protection of a co-created work to be measured starting from the death of the last surviving co-author. ${ }^{17}$ The international copyright treaties that followed the Berne Convention have shown the same reticence towards setting uniform rules as to the merits, as emerges from the Rome Convention, which leaves national laws to regulate the exercise of the rights of performers acting jointly. ${ }^{18}$ Neither the TRIPs Agreement ${ }^{19}$ nor the WIPO Internet Treatie ${ }^{20}$ made any reference to co-authorship whatsoever.

Similarly, the EU legislator has proven to be wary of regulating co-authorship. One of the few, if not the most important, provisions in this regard can be found in the Term Directive of 2006, which, in compliance with the Berne Convention, sets the duration of copyright protection of jointly created works to 70 years from the death of the last surviving author. ${ }^{21}$ The following amendment to the Term Directive in 2011 has added to the implementation of this principle by introducing a specific provision on music works,

14. Arthur Waldenberger, Die Miturheberschaft Im Rechtsvergleich. Zugleich Ein Beitrag Zur Lehre von Der Miturheberschaft Nach Deutschem Recht (Verlag V. Florentz, Munich 1991) 2-3. 15. The first mentions of the possibility of having multiple authors can be found in, among others: the Bill for the Further Encouragement of Learning in the United Kingdom of Great Britain and Ireland of 1801, Paper No.112, I.381-8, paragraph 7 ('Be it therefore further enacted, that the said College [College of the Holy Trinity of Dublin] shall have for ever the sole Liberty of printing and reprinting all such books as shall at any time heretofore have been ... given or assigned by the Author or Authors by the same respectively, or the Representatives of such Author or Authors ...'); the US Copyright Act of 1831, Chapter XVI, Section 2 ('And be it further enacted, That if, at the expiration of the aforesaid term of years, such author, inventor, designer, engraver, or any of them, where the work had been originally composed and made by more than one person ...'); the Austrian Copyright Law of 1846, $\S 8$ ('Where a dramatic work has several joint authors, in case of doubt each one is considered to be entitled to grant permission for its performance'). All cited sources are available in Lionel Bently and Martin Kretschmer (eds), 'Primary Sources on Copyright (1450-1900)' <http:// www.copyrighthistory.org/> accessed 10 July 2018 (emphasis added).

16. "The Convention does not define "works of joint authorship" since the various laws of the Union countries differ widely on the question of how much collaboration there must be to make the contribution of one author indistinguishable from that of the others. The inclusion of definitions, although cutting down ambiguity, is a controversial exercise. The courts can always rule on the point.' World Intellectual Property Organization, 'Guide to the Berne Convention for the Protection of Literary and Artistic Works (Paris Act, 1971)' (Geneva, 1978) 52.

17. Berne Convention for the Protection of Literary and Artistic Works (last amended in 1979) (Berne Convention) art 7 bis.

18. Rome Convention for the Protection of the Performers, Producers of Phonograms and Broadcasting Organizations (as adopted in 1961) (Rome Convention) art 8.

19. WTO Agreement on Trade-Related Aspects of Intellectual Property Rights (15 April 1994).

20. WIPO Copyright Treaty and WIPO Performances and Phonograms Treaty (20 December 1996).

21. Directive 2006/116/EC of the European Parliament and of the Council of 12 December 2006 on the term of protection of copyright and certain related rights [2006] OJ L 372/12 (Term Directive 2006/116/EC) art 1(2). 
which grants equal status of copyright holder to both the author of the lyrics and the music composer. ${ }^{22}$ The impact of this harmonizing provision can be described as twofold: on the one hand, it enhances legal certainty when it comes to the commercialization of songs across the Union, on the other hand it strengthens the protection by granting a de facto extension of the duration of copyrights, as it postpones the entry into the public domain of the whole song to the seventieth year after the last surviving co-author. ${ }^{23}$

Two crucial aspects are worth noting. First, the rule applies exclusively to music works. The rationale behind such a restrictive choice is enshrined in Recital 18, which states:

In some Member States, musical compositions with words are given a single term of protection, calculated from the death of the last surviving author, while in other Member States separate terms of protection apply for music and lyrics. Musical compositions with words are overwhelmingly co-written. For example, an opera is often the work of a librettist and a composer. Moreover, in musical genres such as jazz, rock and pop music, the creative process is often collaborative in nature. ${ }^{24}$

Second, the scenario addressed by the EU legislator involves a low number of co-authors, in all likelihood two individuals. Differently, in the case of works jointly created by higher numbers of contributors, such as movies, EU copyright law leaves national lawmakers to decide whether the directors shall enjoy alone the status of author or rather share the ownership of copyrights with other artists. ${ }^{25}$ The EU regulatory approach to cinematographic and audio-visual works is insightful for the purpose of this paper. Indeed, in order to prevent fragmented durations of rights over movies, which are prima facie collaborative works created by multiple skilled contributors, the EU legislator has imposed the term of 70 years of protection starting from the death of the last survivor of a determined list of persons (ie director, screenplay author, dialogue author and soundtrack composer), ${ }^{26}$ thus 'disentangling the term of protection from the determination of authorship'. ${ }^{27}$ The different approach adopted by the EU legislator with regards to, on the one side, music works and, on the other, movies may be interpreted in light of a particular cautiousness involved

22. Directive 2011/77/EU of the European Parliament and of the Council of 27 September 2011 amending Directive 2006/116/EC on the term of protection of copyright and certain related rights [2011] OJ L 265/1 (Term Directive 2011/77) art 1(1).

23. A useful example is provided by Christina Angelopoulos, from the standpoint of national regulations of co-authorship in EU Member States before the 2011 Amendment to the Term Directive. Said Amendment, indeed, gives as a result the first listed option of unitary, longer copyright protection: 'A classic example is offered by the Gershwin brothers, who collaborated in the production of numerous vocal and theatrical works. In countries where their partnership qualifies as joint authorship, their works will enjoy a single term of protection calculated from the death of Ira, the longest living of the two, in 1983. Otherwise, Ira's works alone will benefit from his longevity, while George's works will be protected as of his own death, giving them a term of protection of 47 years shorter'. Christina Angelopoulos, 'The Myth of European Term Harmonisation: 27 Public Domains for the 27 Member States' (2012) 43 International Review of Intellectual Property and Competition Law 572 (emphasis added).

24. 'Term Directive 2011/77' (n 22) recital 18 (emphasis added).

25. Term Directive 2006/116/EC art 2(1); Directive 2006/115/EC of the European Parliament and of the Council of 12 December 2006 on rental right and lending right and on certain rights related to copyright in the field of intellectual property [2006] OJ L 376/28 (Rental Directive 2006/115) art 2(2).

26. Term Directive 2006/116/EC art 2(2).

27. Angelopoulos (n 23) 572. 
when regulating the circumstance of a potentially high number of individuals cocreating a work. However, this cautious attitude presents an exception. Both the Database and the Software Directives, indeed, provide for joint copyright ownership for, respectively, databases and computer programs collectively created by groups of natural persons, ${ }^{28}$ where the number of potential contributors is often indefinite.

Despite its vast nature, ${ }^{29}$ EU copyright law confines itself to the abovementioned provisions as far as co-authorship is concerned. As a regulatory frame, it is far from substantial: the principle of the last surviving author and the statutory imposition of the status of co-authors upon music composers, lyricists and co-creators of databases and software does not say much, indeed, about who else is entitled to be co-author and how copyrights can be exercised jointly. Nevertheless, there are two relevant elements of warning concealed between the few harmonized provisions on co-authorship here under analysis. With the principle of the last surviving author, the international legislation tries to fix a first main problem, which lies in the fragmentation of duration of copyright entitlements over one single work; with a more cautious approach and, de facto, without providing any guidance as to the merits, the EU hints at a second problem, that is, the potentially arduous exercise of copyrights jointly held by a high number of individuals. By and large, the international and the EU legal frameworks limit themselves to conceiving the possibility of co-authorship and leave national legislators to regulate its definition and core aspects. This lack of uniform regulation can be explained using the same terms adopted by the drafters of the Berne Convention, that is, by the fact that national regulations, with particular regard of the criteria of authorship, ${ }^{30}$ dramatically vary, thus making the legal field too delicate to be reformed. It is no surprise that, in the absence of international and regional standards, national legislators have developed regulatory responses that do not fully converge.

\section{STRICT AND BROAD APPROACHES TO CO-AUTHORSHIP AT NATIONAL LEVEL}

Co-authorship is here analysed as a wide-ranging notion referring to the joint creation of a copyrightable work by more than one person. ${ }^{31}$ National legislations have created sub-categories to regulate its practice, often providing several specific definitions and rules tailored to various types of works (eg for collections of works and movies), rather than a general legal rule. The requirements on which the main differences between

28. Directive 96/9/EC of the European Parliament and of the Council of 11 March 1996 on the legal protection of databases [1996] OJ L 77/20 (Database Directive 96/9) art 4(3); Directive 2009/24/EC of the European Parliament and of the Council of 23 April 2009 on the legal protection of computer programs [2009] OJ L 111/16 (Computer Programs Directive 2009/24) art 2(2).

29. The EU copyright legislation consists of over ten Directives, two main Regulations and numerous Communications of the European Commission. For an overview and related references to the legislative texts see <https://ec.europa.eu/digital-single-market/en/eu-copyright-legislation> accessed 19 July 2018.

30. Irini Stamatoudi and Paul Torremans, EU Copyright Law: A Commentary (Edward Elgar, Cheltenham 2014) 16; Ginsburg (n 10).

31. Particularly worthy of citation is Waldenberger's definition of co-authorship in comparative legal perspective, according to which a work of co-authorship is 'a complex intellectual work of multiple creators, over which more than one author generally (at least partially) is entitled with copyright, to be exercised somehow collectively'. Waldenberger (n 14) 8 (translation from the German by the author). 
national regulations pivot are the subjective element of intention to co-create and the objective element of 'distinguishability' of the contributions, that is, the possibility to perceive them as separated or to separate them for single commercial use.

\section{1 'Strict' co-authorship}

A particularly 'strict' conceptualization of co-authorship ${ }^{32}$ is offered by the German copyright legislation. According to the German Copyright Act, two requirements shall be met in order to qualify as a co-author: first, the contributor's intentional and perceivable collaboration in the joint realization of an original copyrightable work (subjective requirement); and second, the impossibility of separation and exploitation of her own singled-out contribution (objective requirement). ${ }^{33}$ The subjective requirement finds its justification at the core of the copyright discipline, in the centrality of the creative effort, which shall be acknowledged, incentivized and remunerated. ${ }^{34}$ Nevertheless, the most salient component of this requirement is the intention behind the intellectual work, that is the necessary intent to co-create shared by all authors. The German copyright legislation, indeed, regulates in separated provisions the two scenarios where this intention is missing, that is, the cases of adaptations (Bearbeitungen) ${ }^{35}$ and collections of pre-existing works (Sammelwerke). ${ }^{36}$ Under both circumstances, no bond of co-authorship is created and distinct copyright entitlements are at stake; as long as the creator of an adaptation or collection of prior copyrighted works receives the authorization to do so by the respective authors, the latter will maintain full copyright entitlements over their works, while the former will acquire copyright over originally adapted or compiled content.

Looking more closely at the objective requirement, it is revealed as highly characteristic of the 'strict' nature of the German approach to co-authorship. Given that several individuals intentionally pool efforts and skills together to jointly create an original work, the legal definition of co-author further requires their contributions not to be distinguishable or exploited singularly. Here lies a fundamental differentiation between works of co-authorship and compilations of works for the purpose of joint exploitation (Werkverbindungen). ${ }^{37}$ In the latter case, each of the contributors retains the copyright on her own specific creation, without qualifying as co-author and, hence, no joint exercise of rights is involved. ${ }^{38}$ Particular emphasis is loaded on this objective requirement, as the degree of merging of the contributions necessary to qualify as co-authorship is very high. The legal construct of co-authorship becomes therefore a 'strict' (or stricto sensu) co-authorship, according to which it is not enough to purposefully collaborate: the final outcome must be a copyrightable work, which

32. The adjective 'strict' is also used by Stamatoudi and Torremans to describe the peculiar features of legal systems following the German approach to co-authorship. See Stamatoudi and Torremans (n 30) 255-7.

33. $\$ 8(1)$ of the German Copyright Act; Haimo Schack, Urheber- Und Urhebervertragsrecht (Mohr Siebeck, Heidelberg 2017), 160-61.

34. Not fulfilling the subjective requirement are, indeed, contributions consisting of mere ideas, information or mechanical assistance in the creative process following explicit instructions by the creator. Waldenberger (n 14) 14-17.

35. Gesetz über Urheberrecht und verwandte Schutzrechte vom 9. September 1965 (BGB1. I S. 1273) (German Copyright Act) § 3 .

36. German Copyright Act $\S 4$.

37. German Copyright Act $\S 9$.

38. Waldenberger (n 14) 19-20. 
carries signs of the work of each collaborator in such a way that the boundaries and paternity of the single contributions cannot be identified. As a result, a restricted number of co-created works fall under the regulation of the legal institute. ${ }^{39}$

Whenever both the subjective and the objective requirements are met, the contributors, legally qualifying as co-authors, enter a regime of legal community (Gesamthandsgemeinschaft), upon which the doctrinal debate is still very lively. ${ }^{40}$ The joint ownership and exercise of copyrights, in fact, can hardly be interpreted through an analogy with property law institutes such as the community of heirs (Erbgesellschaft) ${ }^{41}$ or the community of share owners (Bruchteilsgemeinschaft), ${ }^{42}$ due to the fact that under German law copyrights - as opposed to property rights are not transferable. ${ }^{43}$ The German legislator has opted for statutorily explicating the legal effect of the co-ownership of copyrights, restricting the joint exercise by co-authors to the economic rights of first publication, commercialization and alteration of the work. ${ }^{44}$ It is worth noting that such restriction operates a regulatory differentiation within the copyright paradigm between moral rights and economic rights, thus potentially unveiling an exceptionally dualistic trait in the strongly rooted monistic copyright tradition of Germany. ${ }^{45}$ The jointly owned rights of exploitation over the co-created work entail that uses by third parties require the unanimous consent by all co-authors, if not otherwise agreed. ${ }^{46}$ The share of revenue granted to each coauthor is measured either according to the extent of her participation in the creation or by way of agreement among the co-authors. ${ }^{47}$

The strict approach to co-authorship epitomized by the German legislation presents three main characterizing features, which can be restated as follows. First, the definition of co-author sets the bar high by requiring single contributions to be undistinguishable in the final work, thus excluding from the legal institute co-created works where it is detectable who has done what. Second, the approach, although regulating a scenario of collaborative creation, mirrors the strongly individual nature of the copyright entitlement: even when efforts are grouped together for the purpose of jointly creating or commercializing a work, the legislator leaves each contributor to retain her own full copyright entitlement over a portion of it, unless her contribution is impossible to distinguish. Third, it is an exploitation-oriented approach, which aims to lower the risk

39. Waldenberger describes $\S 8$ of the German Copyright Act as 'a provision to be interpreted strictly, which is exceptional to the principle stated in $\S 2$ of the German Copyright Act, according to which any personal intellectual creation shall be considered a "work", upon which independent copyright protection lies' Waldenberger (n 14) 25 (translation from the German by the author; emphasis added).

40. Schack (n 32) 163; Waldenberger (n 14) 39-41.

41. Bürgerliches Gesetzbuch in der Fassung der Bekanntmachung vom 2. Januar 2002 (BGBl. I S. 42, 2909; 2003 I S.738), das zuletzt durch Artikel 6 des Gesetzes vom 12. Juli 2018 (BGBl.

I S. 1151) geändert worden ist (German Civil Code) § 2032.

42. German Civil Code $\$ \S 741 \mathrm{ff}$.

43. German Copyright Act $\S 29$.

44. German Copyright Act $\S 8(2)$. See Friedrich Karl Fromm and Wilhelm Nordemann, Urheberrecht (Kohlhammer Verlag, Stuttgart 1988).

45. In the legal doctrine, the different legal treatment of economic (Verwertungsrechte) and moral rights (Urheberpersöhnlichkeitsrechte) was initially highlighted by Otto-Friedrich Freiherr von Gamm, Urheberrechtsgesetz (Beck Verlag, Munich 1968) and by Heinrich Hubmann, Urheber- und Verlagsrecht (Beck Verlag, Munich 1987).

46. The consent cannot be denied against bona fide. See German Copyright Act § 8(2).

47. German Copyright Act $\S 8(3)$. 
of disputes among contributors by avoiding touching co-authors' exclusive rights over their own contributions, whenever those can be distinguished, and providing a default rule of distribution of revenue, when this does not prove possible.

\section{2 'Broad' co-authorship}

Despite the civil law tradition of droit d'auteur shared with the German system, the French copyright law presents an overall opposite approach to co-authorship. Already, by defining the status of author, in the first article of Chapter 3 of the French Intellectual Property Code, the legislation contemplates the possibility of a plurality of subjects. ${ }^{48}$ The legislator defines three typologies of works related to the scenario of multiple contributors: 'work of collaboration' (oeuvre de collaboration) is any work created by more than one individual; ${ }^{49}$ different are 'composite works' (oeuvres composites), which fundamentally lack the collaboration between several authors, as they stem from the mere incorporation of a prior work into a new original one, ${ }^{50}$ and 'collective works' (oeuvres collectives), which refer to the specific circumstance of one person directing the creation of a work consisting of multiple merged contributions (eg encyclopaedia, dictionary, newspaper). ${ }^{51}$ Hence, the collaboration, interpreted as the "community of inspiration, 52 or the 'joint creative control' over the work and the 'good-will agreement' among the coauthors, ${ }^{53}$ plays the role of the watershed requirement between works of co-authorship and other types of co-creation.

The juxtaposition with the strict approach embraces not only the definition of coauthorship, but also the regulation of its legal effects. The copyright over a work of collaboration is, indeed, jointly owned by all its co-authors. Article L113-3 of the French Intellectual Property Code recites:

A work of collaboration shall be the joint property of its authors.

The joint authors shall exercise their rights by common accord.

In the event of failure to agree, the civil courts shall decide.

Where the contribution of each of the joint authors is of a different kind, each may, unless otherwise agreed, separately exploit his own personal contribution without, however, prejudicing the exploitation of the common work. ${ }^{54}$

48. 'Authorship shall belong, unless proved otherwise, to the person or persons, under whose name the work has been disclosed' (emphasis added). Code de la propriété intellectuelle créé par Loi n. 92-597 du 1 juillet 1992 relative au code de la propriété intellectuelle (French Intellectual Property Code) art L113-1.

49. "Work of collaboration" shall mean a work in the creation of which more than one natural person has participated.' French Intellectual Property Code art L113-2(1).

50. "Composite work" shall mean a new work in which a pre-existing work is incorporated without the collaboration of the author of the latter work.' French Intellectual Property Code art L113-2(2).

51. "Collective work" shall mean a work created at the initiative of a natural or legal person who edits it, publishes it and discloses it under his direction and name and in which the personal contributions of the various authors who participated in its production are merged in the overall work for which they were conceived, without it being possible to attribute to each author a separate right in the work as created.' French Intellectual Property Code art L.113-2(3); see also Waldenberger (n 14) 141.

52. Cour de Cassation, Chambre Civil 1, 11 Mai 2017, 16-13.427; Cour de Cassation, Chambre Civil 1, 18 Octobre 1994, 92-17.770.

53. Robert Plaisant, Les Droits des Auteurs et des Artistes Exécutants (Delmas, Paris 1970) 89.

54. French Intellectual Property Code art L113-3 (emphasis added). 
More precisely, all the economic rights are jointly owned - including the right of first publication and of alteration ${ }^{55}$ - whilst moral rights, in full consistency with the dualistic copyright tradition, remain held and enforceable by each co-author, ${ }^{56}$ along with the right to economically exploit her contribution in a particular, noncompetitive market, as long as this creates no prejudice to the exploitation of the final work. ${ }^{57}$ Composite and collective works, on the contrary, do not generate coownership of copyright. Similarly to the German legislation, the author of a work which incorporates an old one, as long as it is used under due authorization, will acquire copyright on the new creation, without interfering with the entitlement over the pre-existing work. ${ }^{58}$ The copyright of a collective work vests instead in the person directing and editing the creative process, under whose name the final work has been disclosed. ${ }^{59}$

The analysis of the French 'broad' (or latu senso) approach to co-authorship, placed in comparison with the German restrictive take, shows a significantly more encompassing nature. ${ }^{60}$ Three aspects are particularly worth highlighting. First, the French definition of co-authored works outlines a vast category (works of collaboration) and two specific circumstances (composite works and collective works). Its systematic interpretation suggests that the rules applying to the works of collaboration are to be intended as general, whilst composite and collective works play the role of specific exceptional cases. Second, the definition of works of collaboration does not provide for objective requirements, thus meaning that collaborative works resulting out of either distinguishable or non-distinguishable contributions can qualify and lead to the joint ownership of copyrights by all co-authors. ${ }^{61}$ These two elements suffice to acknowledge that the French legislator sets the bar lower than the related German provisions, increasing the number of works falling under the regime of joint ownership of copyright.

Third, the broad approach characterizes itself by the prioritization of the agreement between the involved co-creators, be it on the distribution of revenue shares or any other aspect related to the destination of the joint work. Article L113-3 of the French Intellectual Property Code unveils, indeed, the legislator's preference for a joint ownership of copyrights over scenarios of fragmented individual entitlements covering portions of one single co-created work, as is the case in the German legal construct of Werkverbindung. The co-authors' mutual agreement and, hence, a predominant collective dimension lie at the core of the French regulatory approach: for any exploitation of the work, unanimous consent is required and this provision can be overlooked only by way of an explicit agreement between the parties; internal disputes

55. A very interesting reflection on the origin of these two rights from the dimension of moral rights and, hence, on the potentially problematic justification of its joint exercise is provided by Waldenberger (n 14) 184-5.

56. Bernard Parisot, 'L'Inaliénabilité du Droit Moral de l'Auteur d'une Oeuvre Littéraire ou Artistique' [1972] Dalloz 71-2.

57. Thomas Paris, 'La Résistible Vertu Pacificatrice Du Système Du Droit d'Auteur' [2000] Annales des Mines 12-13.

58. French Intellectual Property Code art L113-14.

59. French Intellectual Property Code art L113-15.

60. Waldenberger (n 14) 148.

61. The French doctrine differentiates the two scenarios for the mere purpose of application of Article L113-3 sentence 4, which provides each co-author with the possibility of singularly exploiting her own contribution, if it is of a particular different genre, as long as this does not prejudice the exploitation of the co-created final work. See Waldenberger (n 14) 148-9. 
shall be solved finding a common accord based on acting bona fide ${ }^{62}$ and, if the disagreement persists, a civil judge shall decide. All these scenarios highlight the remarkable incentive supplied by the French legislator towards a collective decision-making process between the contributors, which is comparable to the emphasis that US copyright legislation puts on the intention of the parties to create a unitary work together and share the legal status of co-author. ${ }^{63}$ Indeed, although US copyright law qualifies as 'works of joint authorship' those contents jointly designed and created by more than one individual whose contributions are impossible to distinguish, ${ }^{64}$ the discrimen between co-authorship and the 'work for hire' doctrine, as regulated in the same article of the United States Code ${ }^{65}$ lies in the intention of the contributors: ${ }^{66}$ either they want to be acknowledged by the law as co-authors and, hence, jointly own the copyrights over the work, or they opt for a subordinated contracting relationship between commissioner and creator of the work, leading to one single copyright holder.

Both the French and the US approaches, emphasizing the co-authors' intents and decisions, stand on a doctrinal ground which has consolidated over the centuries to support the shift from the 'romantic author' to a modern conceptualization of creation as a 'collaborative business' ${ }^{67}$ The crucial question arising is whether further evolution in the legal institute of co-authorship is to be expected or wished for in the age of the network society, where co-creation is undergoing a process of substantial growth and consolidation.

\section{THE EXPANSION OF THE CO-PRODUCTION OF SCIENTIFIC KNOWLEDGE}

In order to capture significant trends in the evolving creative world, the analysis should look inside each of its sectors. This paper provides a first insight from the field of scientific knowledge production and aims to make room for similar inquiries into other branches of the EU creative industries. The scientific sector is characterized by highly distinctive incentives to produce content, ${ }^{68}$ which bring to the forefront the

62. The French jurisprudence shows a consolidated practice of application of the doctrine of abuse of rights in cases where a co-author vetos the exploitation of a work without providing any motive. See, among others, André Françon, Cours de propriété littéraire, artistique et industrielle (Les Cours de droit, Paris 1986) 72.

63. Russ VerSteeg, 'Intent, Originality, Creativity and Joint Authorship' (2002) 68 Brooklyn Law Review 144-5.

64. Definition of 'joint work' in 17 United States Code (USC) $\$ 101$.

65. 17 USC $\$ 201(a)$ and (b).

66. 'Intent ... may supply a means to sort out the equities of ownership in cases in which more than one contender is vying for authorship status. There, the problem is not so much whether the contenders intended to be creative, as whether they intended to share the spoils of creativity, that is, whether they intended to be joint owners of the copyright. Certainly, that is the only way that the intent test, applied to determinations of co-authorship in US case law, can be made coherent.' Ginsburg (n 10) 1087.

67. Paris (n 57) 7; Roberta Kwall, 'Author-Stories: Narrative's Implications for Moral Rights and Copyright's Joint Authorship Doctrine' (2001) 75 Southern California Law Review 48.

68. Generally, the motivation behind the production of scientific content is explained in terms of reputational benefits and personal satisfaction in contributing to a wide pursuit of knowledge and truth. See Daniela Simone, 'Recalibrating the Joint Authorship Test: Insights from Scientific Collaborations' (2013) 26 Intellectual Property Journal 118-19; Mario Biagioli and Peter Galison (eds), Scientific Authorship: Credit and Intellectual Property in Science (Routledge, London 2003). 
non-economic benefits ${ }^{69}$ and, in particular, the common pursuit of knowledge by all the actors involved. ${ }^{70}$ As a consequence, the notion of authorship is also peculiar, ${ }^{71}$ having a close-knit connection with the 'scientific authority' of the writer ${ }^{72}$ and often with the structure of the education and academic institutions where the author is employed. ${ }^{73}$ Both these aspects, that is, the underlying incentives to create and the acquisition of scientific authorship, have shown an evolution alongside the advancement of digital technologies. The aim of contributing to a discipline for the purpose of progressing science and technology alongside the aspiration of recognition by one's peers have consolidated as leading motivations to create new knowledge. ${ }^{74}$ This has led towards a twofold development. On the one side, in order to achieve ever more refined and reliable results (and to meet rising quality standards, as a consequence of market competition), ever more frequently researchers pool together efforts, data and information, within the same discipline as well as across scientific sectors. On the other side, when skills and intellectual efforts are shared, creativity finds more numerous ways to express itself through technologically enabled techniques, which may enhance the quality, effectiveness and visibility of the content. ${ }^{75}$

In sum, collaboration has become an option which cannot be overlooked in the process of knowledge production, and, for some disciplines, a proper imperative. ${ }^{76}$ The traditional romantic idea of the solitary scholar devoting her life to science and the arts ${ }^{77}$ leaves room for the phenomena of co-production and peer-production, thus leading to a 'collectivization of science' ${ }^{78}$ This evolution can be detected in two of its main impacts. The first impact is manifested in the increasing quantity of co-created content. Recent surveys show that the co-publishing of academic articles is steadily growing ${ }^{79}$ not without problematic consequences for the reliability of the authorship. ${ }^{80}$ Natural sciences are a long-time champion of this trend, thus presenting consolidated practices to address issues related to multiple authorship, while humanities and social sciences are catching up at a remarkable pace. ${ }^{81}$ This has to do with both the internationalization and the

69. Simone (n 68) 131.

70. Bruce Macfarlane, 'The Ethics of Multiple Authorship: Power, Performativity and the Gift Economy' (2017) 42 Studies in Higher Education 1194-210.

71. Biagioli and Galison (n 68).

72. Simone (n 68) 117.

73. Macfarlane (n 70).

74. Roberta Kwall, 'Copyright Issues in Online Courses: Ownership, Authorship and Conflict' (2002) 18 Santa Clara High Technology Law Journal 20; Biagioli and Galison (n 68).

75. Elizabeth Gadd and Ralph Weedon, 'Copyright Ownership of E-Learning and Teaching Materials: Policy Approaches Taken by UK Universities' (2017) 22 Education and Information Technologies 3231-50.

76. As with the cases of biomedical science and particle physics, as reported by Simone (n 68).

77. Simone (n 68) 119-20.

78. The notion is famously used by Ziman, who builds a thorough analysis and convincing argument on the commercialization of knowledge production methods. See John Ziman, Of One Mind: The Collectivization of Science (American Institute of Physics Press, Washington DC 1995).

79. European Commission, 'European Research Area Progress Report' (2013) EUR26136EN, 284-8; Bruce Macfarlane, 'Co-Authorship in the Humanities and Social Sciences: A Global View' (2018) <http://authorservices.taylorandfrancis.com> accessed 10 June 2018; Simone (n 68), 120-21.

80. In particular regard of the crisis of authorship faced in the biomedical sector, see Simone (n 68) 122.

81. Macfarlane (n 79). 
weaving of networks in scientific environments. ${ }^{82}$ Nowadays, not only is conducting research simpler and cheaper than in pre-internet times, but also the costs of connection with peers and proactive collaboration are much lower. ${ }^{83}$ The second main impact of the 'collectivization of science' lies in the enhancement of the quality and the circulation of content. Co-creation is indeed about the collective selection of data and sources, additional quality checks, and collective decisional processes concerning the research, design and final destination of the content produced. ${ }^{84}$ As a result, co-authored academic publications are more cited ${ }^{85}$ and scientific content is encountering ever newer (mostly software-based) tools of mass distribution of knowledge, from distance learning and weblogs, up to experience-based learning objects. ${ }^{86}$ Studies hint at a predicted further rise in the collaborative production of educational material, both in numbers and variety of supporting formats, along with technological advancements. ${ }^{87}$

Fundamentally missing in this picture are any traces of an impact of the illustrated collaborative trend on the regulatory framework. Overall, even though increasingly networking and pooling their skills and knowledge, authors seem to remain mostly unaware or rather sceptical of copyright rules, ${ }^{88}$ and the legal construct of co-authorship is often perceived merely as a legal remedy for internal disputes arising postexploitation of the work. ${ }^{89}$ Most relevantly for the purpose of this analysis, copyright regulations at both supranational and national level within the EU do not hint at any planned reform concerning the expanding collaborative creative trends. In particular, the swiftly and successfully growing area of co-produced scientific works is not addressed by any EU rules on co-authorship (limited to songs, databases and software), but the harmonized principle of the last surviving author. Who qualifies as co-author, which rights are jointly owned and how to exercise them remain questions answered by highly different, if not opposite, national legislations of the Member States.

82. 'Computers and network connections are ubiquitously distributed throughout the network and around the globe, at least in advanced economies. Teachers, learners, graduate students, and amateurs populate the network in their millions, with diverse abilities, availability, time and attention to spend on developing bits and pieces of educational resources.' Yochai Benkler, Common Wisdom: Peer Production of Educational Materials (COSL Press, Utah, 2005) 26; Wolfgang Glänzel, 'National Characteristics in International Scientific Co-authorship Relations' (2001) 51 Scientometrics 69-115; Wagner and Leydesdorff (n 7) 1609.

83. As Benkler highlights, the main reason lies in the sinking costs of reproduction and distribution: from paper to files, from photocopying machines to email or elearning sites. Benkler (n 82) 7-8.

84. 'If peer production is necessary, it is likely to be focused on the filtering and accreditation of the universe of objects that will be created and accrete in the network as a whole.' Ibid 5.

85. Glänzel (n 82) 78-86.

86. William Fisher III, 'Lessons from CopyrightX' in Ruth Okediji (ed), Copyright Law in an Age of Limitations and Exceptions (CUP, Cambridge 2017); Eric Ras et al., 'Using Weblogs for Knowledge Sharing and Learning in Information Spaces' [2005] Journal of Universal Computer Science 11-19; Benkler (n 82) 23-5.

87. '[Learning] objects can grow and develop over time with small incremental improvements by many users, without limit. ... The growth trajectory is more like that of websites on the WWW than for textbooks.' Benkler (n 82) 25.

88. Casey Fiesler, Jessica L Feuston and Amy S Bruckman, 'Understanding Copyright Law in Online Creative Communities' (2015) Proceedings of the 18th ACM Conference on Computer Supported Cooperative Work \& Social Computing 116-29.

89. Peukert (n 12) 211. 


\section{HARMONIZING EU CO-AUTHORSHIP RULES FOR AN EFFECTIVE EUROPEAN RESEARCH AREA}

Back in 1991, at the dawn of the EU copyright harmonization process, Waldenberger firmly stated the necessity of harmonizing rules on co-authorship in the EU (at the time, the European Community). ${ }^{90}$ His supporting reasoning was based on the market distortions that diverging national regulations in the matter entail and in the full competence of the EU legislator to intervene for the good of the internal single market. The most recent Digital Single Market Strategy, that is the policy plan guiding the on-going reform of EU copyright rules, has set its first priority as the smoothing of the internal market with regard to protected content and its online circulation. ${ }^{91}$ In addition to the competence of the EU legislator and the benefits for the internal market, the legal scholarship has largely developed a further argument in favour of the harmonization of co-authorship, according to which spontaneous practices, in scientific knowledge production as well as in other sectors, should be aligned with copyright rules to make these effective. ${ }^{92}$ The EU legislator has not fully followed any of those suggestions yet. The choice of putting music composers and lyricists, as with co-creators of databases and computer programs, on equal footing, granting them ex lege the status of co-author - although lacking definition and substantial regulation prompts the questions: why only those categories? Are songs the only works 'overwhelmingly co-written' and 'collaborative in nature'? As seen, the production of scientific content offers a fitting example to consider the possibility of further expansion of the scope of EU rules on co-authorship.

The EU has posited a clear-cut objective which concerns the scientific sector, that is, the achievement and fostering of a well-functioning European Research Area (ERA). ${ }^{93}$ The policy paths embedded in the Digital Single Market Strategy and in the ERA plan dovetail with each other, and both envisage proactive coordination by the Directorate-General for Research and Innovation, whose stance is emblematically represented by the following statement:

An effective European Research Area will contribute to a single market for knowledge in Europe. To this end, it is not sufficient to enhance the system - research performers and users also need to be stimulated to take up the opportunities offered to them and use the system for collaborative knowledge production. ${ }^{94}$

The EU aims to advance the quality and quantity of scientific content produced within the Union by way of enhancing the opportunities for collaboration between researchers. This fundamentally adds to the purposes of a competitive single market and effective copyright regulation as one further reason to implement a more substantial

90. Waldenberger (n 14) 269-86.

91. European Commission, 'A Digital Agenda for Europe' (Communication) COM(2010) 245 final/2, 26 August 2010.

92. 'It is important that copyright law remains connected to creative communities' own understandings about authorship in order to maintain its credibility as an important tool for encouraging and regulating creativity.' Simone (n 68) 132; Sean Seymore, 'How Does My Work Become Our Work? Dilution of Authorship in Scientific Papers, and the Need for the Academy to Obey Copyright Law' (2006) 12 Richmond Journal of Law and Technology 11. 93. European Commission, 'Towards a European Research Area' (Communication) COM/ 2000/0006 final 6.

94. European Commission, 'European Research Area Progress Report' (n 79) 284-8 (emphasis added). 
harmonization of co-authorship rules. The highly limited intervention of the EU legislator in the matter shows an inclination towards the 'boad' approach to co-authorship, providing music composers and lyricists, and the co-creators of software and databases with the legal status of co-authors without imposing any specific objective requirements on the nature of their contributions. ${ }^{95}$ The first main element drawing a demarcation line between sceptical and supporting legislative approaches to co-authorship at the national level is, indeed, the presence of additional objective requirements to enter a legal regime of co-ownership of copyrights.

If the EU legislator followed a strict approach, the category of co-authored works, including the production of scientific content for research and educational purposes, would be limited to those stemming from highly merged contributions. Two main consequences would be expected. First, the problem of fragmentation of copyright duration would emerge for those works not falling under the definition of co-authorship (eg research or educational material designed by multiple authors through a clear-cut division of tasks). Second, legal uncertainty could not be ignored with regard to determining the distinguishability of the contributions (eg in the case of distance learning and interactive teaching materials, where the educational content and the audio-visual and software development bring about a new form of two halves of the same work) as well as with regard to the mechanism for quantifying the shares of revenue, which - if not preventively agreed upon by the parties - may be hard to reconcile with the required high degree of merging of the contributions.

On the contrary, the broad approach to co-authorship may include all works created by multiple authors under a common project, disregarding the division of tasks and features of contribution. Besides overcoming problems related to the dubious determination of the distinguishable nature of contributions, this approach leads to three main legal effects, which are in line with the policy goal expressed by the Directorate-General in support of the ERA plan, that is, to stimulate researchers and facilitate their collaborative knowledge production: (i) it significantly lowers the risk of rights fragmentation by imposing joint ownership of copyright on most of the co-created works; (ii) it enhances legal certainty by empowering co-authors relying upfront on their mutual agreement; and finally (iii) it grants flexibility to the scientific areas to develop practices on an aggregate level which respond to sector-specific needs. Empirical studies have proven enhanced effectiveness in the exercise and management of copyrights in specific scientific sectors, which are turning into sustainable methods of collaboration and production of knowledge, where the authors have wide room to decide upon the joint exercise of rights. ${ }^{96}$ In particular, Simone takes into consideration how scientific communities have self-developed efficient ways to deal with copyright rules in largely collaborative projects. ${ }^{97} \mathrm{Her}$ conclusions highlight how flexibility is utterly needed within the legal construct of co-authorship for the purpose of 'allow[ing] for a contextual approach that can adapt

95. Interestingly, also the WIPO draft model law on copyright presented the broad approach in its definition of co-authorship. See WIPO Committee of Experts on Model Provisions for Legislation in the Field of Copyright, 'Draft Model Provisions for Legislation in the Field of Copyright' (Memorandum prepared by the International Bureau of the WIPO) Doc. No. CE/MPC/I/2-II, 20 October 1988, section 1(xx).

96. See, among others, the results of the empirical studies concerning the scientific sector conducted by Ann Louise Monotti and Sam Rickeston, Universities and Intellectual Property: Ownership and Exploitation (OUP, Oxford 2003) as well as the conclusions by Gadd and Weedon (n 75).

97. Simone (n 68) 113. 
to the creative methods of large collaborations'. ${ }^{98}$ She suggests that opting for the requirement of a 'common design' to qualify co-authors would set a clear standard for collaborations and still provide room for contextual application to a judge. ${ }^{99}$ In line with the argument posited by Simone, it is here put forward that a broad approach to co-authorship would respond to the set goal of fostering the co-production phenomenon to achieve an increase in high-quality and technologically advanced scientific content within the EU, thus fully acknowledging the added value embedded in authors' collaboration.

\section{CONCLUSIONS}

Starting from observation of the network society, in which, facilitated by the evolving digital technologies, individuals have better and facilitated chances to co-create, this analysis has tackled the legal construct of co-authorship to inquire whether copyright rules within the EU are responding effectively to the changes occurring in the creative industries. The paper has shown that multiple authorship is envisioned at the international and EU level, yet is not addressed by a substantial body of uniform copyright rules, and related national provisions vary significantly. Exemplary are the cases of the German and French legislations, which respectively look at co-authorship scenarios as costly situations of potential conflict among creators or, in the opposite way, as an opportunity to value the participation of every contributor to the creative process.

A case has been raised for substantial harmonization at EU level of the rules on co-authorship to promote scientific cooperation. The analysis has indeed detected a mismatch between the static and divergent regulatory framework of co-authorship within the Union and the EU policy objective of promoting collaborative knowledge production. The need to address such a mismatch acquires relevance as the phenomenon of co-production steadily grows. In today's scientific sector we are witnessing an increase in co-authored works, both in the form of academic publications and teaching materials. A close analysis of the field can provide a meaningful insight into the consolidation of technologically enabled and collaborative trends in the creative industries. In this vein, the paper has shown that a substantial EU harmonization of co-authorship rules, as far as it is inclusive in its definition and relies on the mechanisms of consensus among co-authors, would be able to enhance the quantity and quality of co-produced scientific knowledge, thus supporting the plan of an open and collaborative European Research Area. On the contrary, what has been named a 'strict' regulatory approach to the joint ownership of copyright by multiple persons may eventually stifle innovative collaborations and bring about legal uncertainty by holding to a deeply individual nature of copyright and fragmenting the duration of exclusive entitlements over one single work. The results of the analysis are in line with the functions of EU copyright law in overcoming market distortions to facilitate a well-functioning digital single market and filling the gaps of policy guidance on, for instance, what to do with large groups of co-authors. Looking at the practices developed by the same protagonists regarding copyright protection in the EU seems therefore the path to follow.

98. Ibid.

99. Ibid 133. 